\title{
An evaluation of the inflammatory response of lipopolysaccharide-treated primary dental pulp cells with regard to calcium silicate-based cements
}

\author{
Wei-Yun Lai ${ }^{1,2}$, Chia-Tze Kao ${ }^{1,2}$, Chi-Jr Hung ${ }^{1,2}$, Tsui-Hsien Huang ${ }^{1,2, *}$ and Ming-You Shie ${ }^{3, *}$
}

This study compared the biological changes of lipopolysaccharide (LPS)-treated dental pulp (DP) cells directly cultured on mineral trioxide aggregate (MTA) and calcium silicate (CS) cements. DP cells were treated with LPS for $24 \mathrm{~h}$. Then, the LPS-treated DP cells were cultured on MTA or CS cements. Cell viability, cell death mechanism and interleukin (IL)-1 $\beta$ expressions were analysed. A one-way analysis of variance was used to evaluate the significance of the differences between the means. A significantly higher IL-1 $\beta$ expression (2.9-fold) was found for LPS-treated cells $(P<0.05)$ compared with DP cells without LPS treatment at $24 \mathrm{~h}$. Absorbance values of LPS-treated cells cultured on CS cement were higher than a tissue culture plate. A significant difference $(P<0.05)$ in cell viability was observed between cells on CS and MTA cements $24 \mathrm{~h}$ after seeding. At $48 \mathrm{~h}$, a high concentration of Si (5 mM) was released from MTA, which induced LPS-treated DP cell apoptosis. The present study demonstrates that CS cement is biocompatible with cultured LPS-treated DP cells. MTA stimulates inflammation in LPS-treated DP cells, which leads to greater IL-1 $\beta$ expression and apoptosis. International Journal of Oral Science (2014) 6, 94-98; doi:10.1038/ijos.2014.5; published 21 February 2014

Keywords: calcium silicate cement; dental pulp cell; mineral trioxide aggregate; immune response; interleukin-1 $\beta$

\section{INTRODUCTION}

Mineral trioxide aggregate (MTA) is a root repair material that has several clinical applications in endodontics. ${ }^{1}$ MTA is a mixture of $75 \%$ Portland cement, $20 \% \mathrm{Bi}_{2} \mathrm{O}_{3}$ and $5 \%$ gypsum $\left(\mathrm{CaSO}_{4} \cdot 2 \mathrm{H}_{2} \mathrm{O}\right)$. It received the approval of the US Federal Food and Drug Administration in 1998. ${ }^{1}$ Several studies have shown that MTA has better biocompatibility than other materials used in root-end fillings and root repairs. ${ }^{2-5}$ It has also been shown to enhance hard-tissue formation. ${ }^{6}$ The components of MTA are calcium silicate, tricalcium aluminates, tetracalcium aluminoferrite and gypsum. ${ }^{7}$ A new calcium silicate (CS) cement containing $\mathrm{CaO}, \mathrm{SiO}_{2}, \mathrm{Al}_{2} \mathrm{O}_{3}$ and $\mathrm{ZnO}$, which was developed by our laboratory has a shorter setting time $(13 \mathrm{~min})$ than MTA $(151 \mathrm{~min}) .{ }^{8}$ When hardened with water, CS cement has a similar elemental composition to set MTA. CS cement not only exhibits acceptable osteoconduction effects, ${ }^{9-10}$ but also reduces the inflammation of primary dental pulp (DP) cells. ${ }^{11}$

In apicoectomy, the apex's surrounding tissue environment is related to bacteria-induced local metabolic acidosis. The inflammatory responses of different tissues to MTA were evaluated in a BALB/c mouse injection study; when MTA ( $25 \mathrm{mg}$ per cavity) was injected into normal and pre-treated peritoneal cavities, it induced neutrophil recruitment. ${ }^{12-13}$ An MTA implant study using Wistar albino rats showed that inflammatory cells surrounded the implant by the sixtieth day. ${ }^{14}$ Moreover, inflamed cell apoptosis was associated with environmental factors. ${ }^{15}$ White-coloured MAT (WMAT) mixed with $\mathrm{H}_{2} \mathrm{O}$ has a deleterious effect on physical and chemical properties under acidic conditions. ${ }^{16}$ The number of ions dissolved from MTA increased under a low $\mathrm{pH}$ physiological buffer. ${ }^{16}$ More Si ions can be created via dissolution from a silicate-based material; this procedure appears to stimulate cell apoptosis. ${ }^{17-18}$ Therefore, the use of lipopolysaccharide (LPS)-treated cells to evaluate material biocompatibility is close to clinical use.

Our previous study demonstrated that CS has better cytocompatibility than MTA. ${ }^{9}$ However, little information is available regarding the involvement of MTA or CS cement in the cell behaviour of inflammatory cells or tissue. The present study investigates the inflammatory marker interleukin (IL)-1 $\beta$ and the biological changes of LPS-treated DP cells directly cultured on MTA or CS cements.

\section{MATERIALS AND METHODS}

DP cell isolation and culture

The DP cells were freshly derived from caries-free, intact premolars extracted for orthodontic treatment, as previously described. ${ }^{19}$ The patients provided informed consent, and approval from the Ethics

\footnotetext{
${ }^{1}$ School of Dentistry, Chung Shan Medical University, Taichung City, Taiwan; ${ }^{2}$ Department of Dentistry, Chung Shan Medical University Hospital, Taichung City, Taiwan and ${ }^{3}$ Institute of Oral Science, Chung Shan Medical University, Taichung City, Taiwan

*These authors contributed equally to this work.

Correspondence: Dr TH Huang, School of Dentistry, Chung Shan Medical University, Taichung City 402, Taiwan

E-mail: thh@csmu.edu.tw

Dr MY Shie, Institute of Oral Science, Chung Shan Medical University, Taichung City 402, Taiwan

E-mail: eviltacasi@gmail.com
}

Accepted 18 December 2013 
Committee of the Chung Shan Medicine University Hospital was obtained (CSMUH No. CS11187). The tooth was split sagittally with a chisel. The pulp tissue was then immersed in a phosphate-buffered saline (PBS; Caisson, North Logan, UT, USA) solution and digested in $0.1 \%$ collagenase type I (Sigma-Aldrich, St Louis, MO, USA) for $30 \mathrm{~min}$. After being transferred to a new plate, the cell suspension was cultured in Dulbecco's modified Eagle's medium (DMEM; Caisson, North Logan, UT, USA), supplemented with $20 \%$ foetal bovine serum (FBS; Caisson, North Logan, UT, USA), $10 \mathrm{U} \cdot \mathrm{mL}^{-1}$ penicillin $\mathrm{G}$ solution and $10 \mathrm{~g} \cdot \mathrm{L}^{-1}$ streptomycin (Caisson, North Logan, UT, USA) in a humidified atmosphere with $5 \% \mathrm{CO}_{2}$ at $37{ }^{\circ} \mathrm{C}$; the medium was changed every 3 days. The cells were subcultured via successive passaging at a $1: 3$ ratio until they were used for the experiment (passages 3-8). Then, the DP cells were cultured on tissue culture plates and pre-treated with $200 \mu \mathrm{g} \cdot \mathrm{L}^{-1} \mathrm{LPS}$ (Sigma-Aldrich, St Louis, MO, USA) in DMEM for 12 and $24 \mathrm{~h}$.

\section{IL-1 $\beta$ expression}

Western blot was used to evaluate IL-1 $\beta$ protein expression in LPStreated DP cells. After the incubation period, the DP cells were lysed in a buffer and centrifuged at $16000 \mathrm{~g}$ for $30 \mathrm{~min}$ at $4{ }^{\circ} \mathrm{C}$. The protein concentration of the lysates was measured using the DC Protein Assay kit (Bio-Rad, Richmond, CA, USA). These protein samples $(25 \mu \mathrm{g})$ were separated using sodium dodecyl sulfate-polyacrylamide gel electrophoresis, transferred to nitrocellulose membranes and incubated with primary antibodies against IL-1 $\beta$ (GTX22105, 1:3 000; GeneTex, San Antonio, TX, USA) and $\beta$-actin (GTX300041, 1:5000; GeneTex, San Antonio, TX, USA). Membranes were washed with PBS-T (PBS containing $0.1 \%$ Tween 20 ) and incubated using the appropriate horseradish peroxidase-conjugated secondary antibody for $1 \mathrm{~h}$. After the incubation period, the membranes were washed with PBS-T and incubated on an enhanced chemiluminescent substrate. The stained bands were scanned and quantified using a densitometer (Syngene Bioimaging System, Syngene, Frederick, MD, USA) and Scion Image software (Scion Corp., Frederick, MD, USA).

\section{Calcium silicate-based specimen preparation}

White-coloured ProRoot MTA (Dentsply, Tulsa, OK, USA) and CS (composition: 65\% $\mathrm{CaO}, 25 \% \mathrm{SiO}_{2}, 5 \% \mathrm{Al}_{2} \mathrm{O}_{3}$ and $5 \% \mathrm{ZnO}$ ) cements ${ }^{8}$ were used in present study. In brief, appropriate amounts of asreceived $\mathrm{SiO}_{2}, \mathrm{CaO}, \mathrm{Al}_{2} \mathrm{O}_{3}$ and $\mathrm{ZnO}$ powders were mixed at $1000 \mathrm{r} \cdot \mathrm{min}^{-1}$ for $10 \mathrm{~min}$ using a hybrid-defoaming mixer (ARE250; Thinky, Tokyo, Japan). The oxide mixtures were then sintered at $1400{ }^{\circ} \mathrm{C}$ for $2 \mathrm{~h}$ using a high-temperature furnace. The sintered granules were then ball-milled in ethyl alcohol using a centrifugal ball mill (S 100; Retsch, Hann, Germany) for $6 \mathrm{~h}$. The CS powder (0.6 g) was mixed using a liquid/powder ratio of $0.35 \mathrm{~mL} \cdot \mathrm{g}^{-1}$. After mixing, the cement fully covered each well of the 24-well plate (GeneDireX, Las Vegas, NV, USA) to a thickness of $2 \mathrm{~mm}$, and the plate was stored in an incubator at $100 \%$ relative humidity and $37^{\circ} \mathrm{C}$ for 1 day of hydration. According to the MTA manufacturer's instructions, a liquid/powder ratio of $0.3 \mathrm{~mL} \cdot \mathrm{g}^{-1}$ was used to mix the cement. Before the experiments, all specimens were sterilised via soaking in a $75 \%$ ethanol solution and exposure to ultraviolet light for $1 \mathrm{~h}$.

\section{Cytotoxicity}

LPS-treated DP cell suspensions (at a density of $10^{4}$ cells per $\mathrm{mL}$ ) were directly seeded over each specimen and incubated at $37{ }^{\circ} \mathrm{C}$ in a $5 \% \mathrm{CO}_{2}$ atmosphere; the medium was changed every 3 days. After different culturing times, cell cytotoxicity was evaluated using the PrestoBlue assay (Invitrogen, Grand Island, NY, USA). The reagent PrestoBlue was used for real-time and repeated monitoring of cell proliferation; this method is based on the detection of mitochondrial activity. At the end of the culture period, the medium was discarded and the wells were washed with PBS. Each well was filled with a 1:9 solution of PrestoBlue in fresh DMEM and incubated at $37{ }^{\circ} \mathrm{C}$ for $30 \mathrm{~min}$. The solution in each well was transferred to a new 96-well plate. The plates were analysed using a multiwell spectrophotometer (Hitachi, Tokyo, Japan) at $570 \mathrm{~nm}$ with a reference wavelength of $600 \mathrm{~nm}$. Cells cultured on a tissue culture plate were used as a control. The results were obtained in triplicate from six separate experiments for each test.

\section{Ion concentrations}

$\mathrm{Si}$ and $\mathrm{Ca}$ ion concentrations from the DMEM (after being cultured with LPS-treated DP cells on MTA and CS cements) were analysed using an inductively coupled plasma-atomic emission spectrometer (OPT 1MA 3000DV; Perkin-Elmer, Shelton, CT, USA) at 12, 24 and $48 \mathrm{~h}$. Six samples were measured for each data point.

\section{Apoptosis and necrosis analysis}

Annexin V/propidium iodide (PI) staining confirmed that a significant proportion of treated cells displayed phosphatidylserine externalisation during early phase apoptosis $\left(\mathrm{Ann}^{+}, \mathrm{PI}^{-}\right)$. The numbers of cells that were viable $\left(\mathrm{Ann}^{-}, \mathrm{PI}^{-}\right)$, exhibited late apoptosis $\left(\mathrm{Ann}^{+}, \mathrm{PI}^{+}\right)$and necrosis $\left(\mathrm{Ann}^{-}, \mathrm{PI}^{+}\right)$were determined accordingly. ${ }^{1,20}$ At 12,24 and $48 \mathrm{~h}$, floating and adherent cells were collected, centrifuged and fixed in cold ethyl alcohol at $-20{ }^{\circ} \mathrm{C}$ overnight. The adherent cells were detached using trypsin-EDTA (Caisson, North Logan, UT, USA). Then, cell samples were collected, centrifuged and stained with PI and annexin V-fluorescein isothiocyanate (Invitrogen, Grand Island, NY, USA) in $1 \mathrm{~mL}$ of PBS in the dark at $4{ }^{\circ} \mathrm{C}$. The resulting cell suspension was analysed using a flow cytometer (FACSCalibur; Becton Dickinson, Franklin Lakes, NJ, USA). The sample was evaluated using Win MDI 2.8 software (Scripps Research Institute, La Jolla, CA, USA). The average of six assays was recorded.

\section{Data analyses}

A one-way analysis of variance was used to evaluate the significance of the mean differences between the experiment groups and the control. Scheffe's multiple comparison test was used to determine the significance of the deviations in the data for each specimen. In all cases, the results were considered significant at a $P$ value of $<0.05$.

\section{RESULTS}

\section{LPS-induced DP cell inflammation}

The effects of LPS on DP cell IL-1 $\beta$ expression are shown in Figure 1. IL-1 $\beta$ expression increased with increasing DP cell culture time $(P<0.05)$. The 24 -h group showed a 1.7 -fold higher IL-1 $\beta$ expression $(P<0.05)$ than the 12-h group.

\section{DP cell viability}

The viabilities of LPS-treated DP cells cultured on MTA or CS cements are shown in Figure 2. LPS-treated cell viability was not significantly different $(P>0.05)$ among the three groups after $12 \mathrm{~h}$ of culturing. A significant difference $(P<0.05)$ in the DP cell viability on CS and MTA cements was observed at 24 and $48 \mathrm{~h}$ after seeding. The DP cell viability of the MTA group was the lowest at $48 \mathrm{~h}(P<0.05)$.

\section{Ion concentration}

$\mathrm{Si}$ and Ca ion concentrations in DMEM (after being cultured with LPS-treated DP cells) on MTA and CS cements for various time 
DMEM_12 LPS_12 DMEM_24 LPS_24

IL-1 $\beta(31 \mathrm{kDa})$

$\beta$-actin (42 kDa)

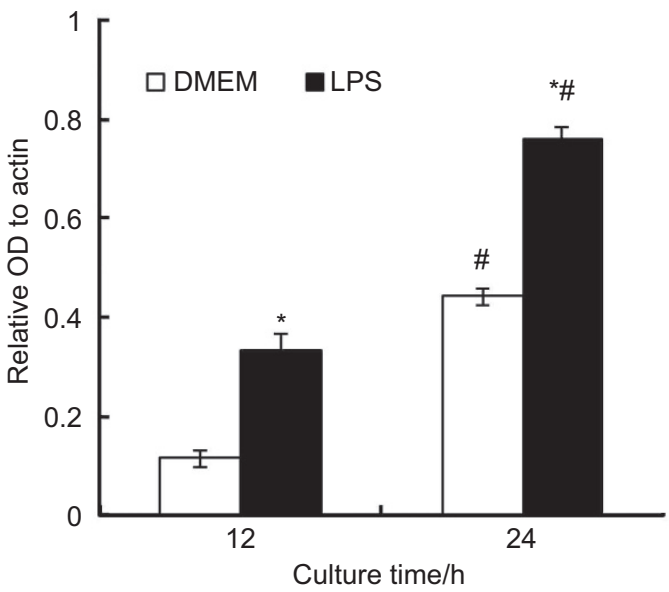

Figure 1 Comparing the IL-1 $\beta$ expression of DP cells treated with or without LPS $\left(200 \mu \mathrm{g} \cdot \mathrm{L}^{-1}\right)$ for 12 and $24 \mathrm{~h}$. $* P<0.05$, compared with DMEM. ${ }^{\#} P<0.05$, compared with $12 \mathrm{~h}$. DMEM, Dulbecco's modified Eagle's medium; DP, dental pulp; IL, interleukin; LPS, lipopolysaccharide; OD, optical density.

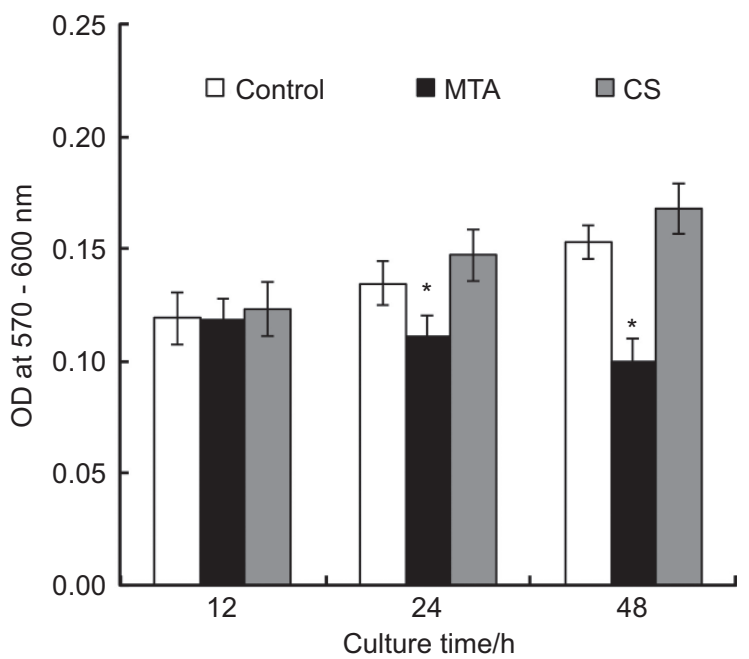

Figure 2 PrestoBlue assay for LPS-treated DP cell viability on MTA or CS cements at various time points. $* P<0.05$, compared with the control. CS, calcium silicate; DP, dental pulp; LPS, lipopolysaccharide; MTA, mineral trioxide aggregate; OD, optical density.

periods are shown in Figure 3. After $12 \mathrm{~h}$, the Si concentrations in the MTA group $(4.6 \pm 0.2) \mathrm{mmol} \cdot \mathrm{L}^{-1}$ were significant higher than those in the CS group $\left((3.0 \pm 0.1) \mathrm{mmol} \cdot \mathrm{L}^{-1} ; P<0.05\right)$. Si concentrations increased with incubation time (Figure $3 \mathrm{a}$ ). The Ca ion concentration of the medium increased after $12 \mathrm{~h}$ of incubation and then decreased to approximately $0.9 \mathrm{mmol} \cdot \mathrm{L}^{-1}$ after $48 \mathrm{~h}$, which was lower than the baseline Ca concentration of DMEM $\left(1.8 \mathrm{mmol} \cdot \mathrm{L}^{-1}\right.$; Figure $\left.3 \mathrm{~b}\right)$.
Cell death analysis

The numbers of LPS-treated DP cells on control and CS substrates did not significantly differ at any time point (Figure 4). A significant reduction was observed with regard to the living cells in the MTA group, which dropped to $70.27 \%$ at $48 \mathrm{~h}$ from $93.16 \%$ at $12 \mathrm{~h}$ $(P<0.05)$. Compared with LPS-treated cells, the percentage of Ann
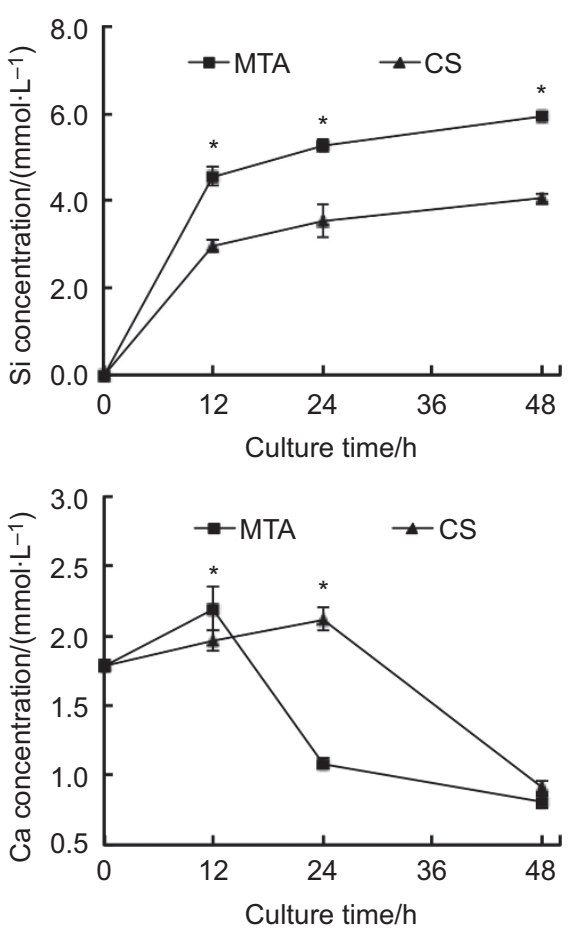

Figure $3 \mathrm{Si}$ and $\mathrm{Ca}$ ion concentrations of LPS-treated DP cells cultured on MTA and CS cements, respectively, at various time points. $* P<0.05$, compared with CS. CS, calcium silicate; DP, dental pulp; LPS, lipopolysaccharide; MTA, mineral trioxide aggregate.

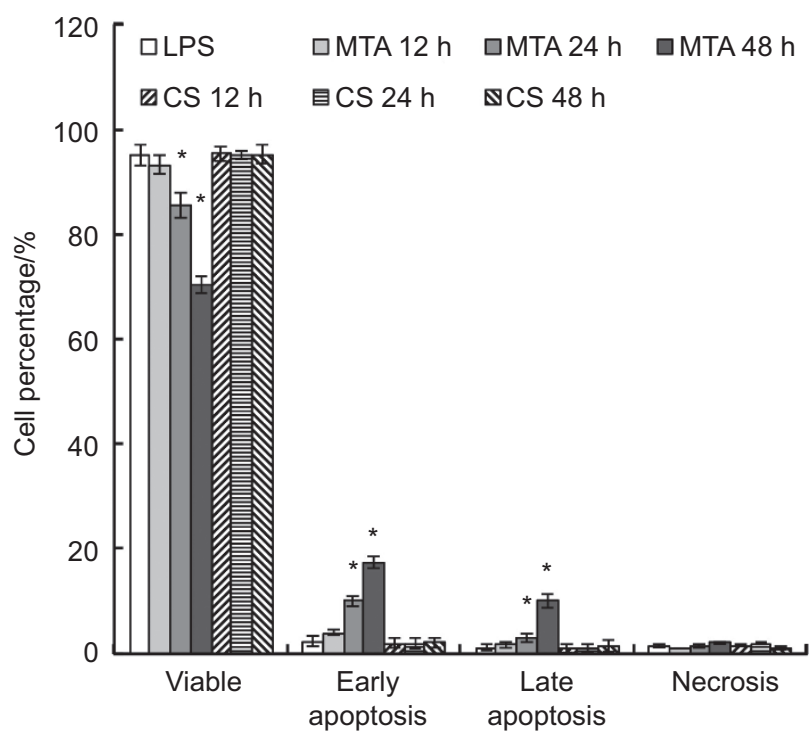

Figure 4 Quantitative analysis results of the LPS-treated DP cells cultured on MTA or CS cements at various time points. $* P<0.05$, compared with the LPSgroup. CS, calcium silicate; DP, dental pulp; LPS, lipopolysaccharide; MTA, mineral trioxide aggregate. 

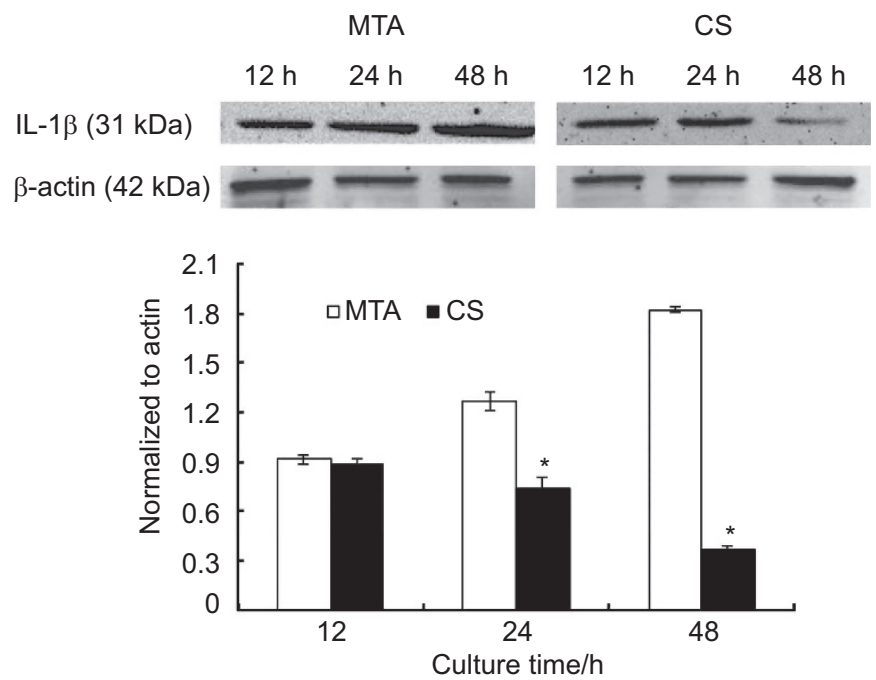

Figure 5 IL-1 $\beta$ expression of LPS-treated DP cells cultured on MTA or CS cements. ${ }^{*} P<0.05$, compared with MTA. CS, calcium silicate; DP, dental pulp; LPS, lipopolysaccharide; MTA, mineral trioxide aggregate.

V-positive cells increased significantly $(P<0.05)$ after being cultured on MTA for $24 \mathrm{~h}$ (3.8-fold) and $48 \mathrm{~h}$ (8.0-fold). In contrast, no differences were observed between the proportions of necrotic cell deaths for cells on MTA or CS cements at any time point $(P>0.05)$.

\section{IL-1 $\beta$ expression}

At $12 \mathrm{~h}$, IL-1 $\beta$ expressions did not significantly differ $(P>0.05)$ between cells on MTA and CS cements (Figure 5). The IL-1 $\beta$ expression of the MTA group increased with culturing time. In contrast, IL-1 $\beta$ expression decreased after culturing on the CS cement for 24 and $48 \mathrm{~h}$. The IL-1 $\beta$ expression level for the CS group was significantly lower $(P<0.05)$ than that of the MTA group at both 24 and $48 \mathrm{~h}$.

\section{DISCUSSION}

Ideal root-end filling materials should possess acceptable biocompatibility. Cell exposure to certain root-end filling materials results in immunotoxic effects. ${ }^{1,21}$ Biomaterials are foreign to the host body, and the magnitude and duration of the inflammatory process directly affect biocompatibility. $^{2-4,10,22}$ The $\mathrm{pH}$ value of the environment surrounding the materials can change from neutral to acidic due to inflamed tissue-induced local acidosis. ${ }^{6,23}$ Apoptosis due to the inflammatory cell itself is associated with environmental factors. ${ }^{7,15}$ Therefore, the mechanism associated with the root-end filling material effects on inflammatory tissue should be clarified.

The physical and chemical properties of MTA and CS cements are similar. ${ }^{8-9,11}$ Low solubility is a necessary characteristic for a root-end filling material with regard to successful endodontic therapy. $\mathrm{Ca}^{2+}$ release from MTA was faster than that from CS cement at $12 \mathrm{~h}$. In addition, the initial increase of $\mathrm{Ca}$ ion concentration corresponded to the dissolution of $\mathrm{Ca}(\mathrm{OH})_{2}$ and an increase in the $\mathrm{pH}$ of the environment. ${ }^{9,24,25}$ Changes in extracellular $\mathrm{pH}$ are likely to induce cell death because they change the potential across the cell membrane, and ion exchange systems could be inhibited. A high $\mathrm{Ca}^{2+}$ concentration can induce apoptosis and DNA fragmentation. ${ }^{10,26,27}$ This effect might result in a build-up of intracellular $\mathrm{pH}$ and protein denaturation. ${ }^{12,28}$

LPS is an outer membrane component of a Gram-negative bacteria that induces several inflammations, such as matrix metalloproteinase (MMP)-2 and MMP-9, and many cytokines (IL-1 $\beta$, IL-6 and so on) in inflamed cells, thereby leading to the destruction of host tissues. ${ }^{14,29,30}$ IL- $1 \beta$ production in DP cells can be stimulated using LPS, ${ }^{14,29}$ and IL- $1 \beta$ is highly expressed in inflamed pulp tissues. ${ }^{15,31}$ Bacterial components might also play an important role in pulpitis. ${ }^{15,29}$ Therefore, the present study stimulated DP cell inflammation with LPS for 12 and $24 \mathrm{~h}$, and compared IL- $1 \beta$ expression in LPS-treat DP cells with that of untreated cells. IL-1 $\beta$ formation increased with culture time. The increase in IL- $1 \beta$ molecule formation in DP cells indicates the presence of inflammation. ${ }^{17,18,32}$

The viability of LPS-treated DP cells cultured on CS cement was greater than that of cells cultured on MTA for all time points. ${ }^{8,11}$ Interestingly, the number of LPS-treated DP cells cultured on CS cement increased with culturing time. In contrast, MTA gradually reduced LPS-treated DP cell viability up until $48 \mathrm{~h}$. MTA might have released Si ions into the medium, thereby leading to LPS-treated DP cell death. After cell culturing on MTA for 24 and $48 \mathrm{~h}$, the dissolved Si concentration in DMEM was higher than $5 \mathrm{mmol} \cdot \mathrm{L}^{-1}$, enabling the induction of cell apoptosis. ${ }^{18}$ Bioactive silicate-based substrates (which release $\mathrm{Si}$ ions) can enhance new hard tissue formation. ${ }^{33} \mathrm{Si}$ ion concentration is a key factor in cell behaviour. ${ }^{17,34}$ The dissolution of silanol ( $\mathrm{Si}-\mathrm{OH})$ formed an amorphous $\mathrm{SiO}_{2}$ phase that increased the Si ion concentration of the culture medium. ${ }^{35}$ The medium might have contained an excess of osmolytes (inorganic ions) after cell culturing on MTA, and cells can be stimulated to apoptosis in hyperosmolality. ${ }^{36}$ Si ion concentration might regulate apoptosis, proliferation and other cell behaviours. ${ }^{18}$ However, the high number of Si ions released from MTA caused hyperosmoticity in the medium, which induced IL-1 $\beta$ expression, possibly via the 338 pathway. ${ }^{37}$

IL- $1 \beta$ expression was high in LPS-treated DP cells, and this expression increased with time among cells cultured on MTA; furthermore, this expression was greater than that of cells on CS cement after culturing for 24 and $48 \mathrm{~h}$. MTA might have induced the acute inflammatory response via the calcium oxide dissolved in the body's fluids, ${ }^{8}$ which can increase the $\mathrm{pH}$ surrounding the tissue and stimulate IL-1 and inducible nitric oxide synthase (iNOS) expression. ${ }^{38}$ Similarly, an MTA implant study using Wistar albino rats showed that more inflammatory cells surrounded the implant at the sixtieth day. ${ }^{14}$ Angelus MTA caused moderate reactions at day 7, and these reactions decreased with time. ${ }^{39}$ The CS cement caused LPS-treated DP cells to moderately react after day 1; however, the inflammation marker decreased with time. ${ }^{11}$ These results consistently indicated that an appropriate Si concentration released from CS cement effectively supports the proliferation of DP cells and reduces the biological response of cells through the production of inflammation proteins.

In conclusion, the present study demonstrated that MTA stimulates LPS-treated DP cells such that IL-1 $\beta$ expression and apoptosis increase. In contrast, CS cement is biocompatible and enhanced LPS-treated DP cells' proliferation. Therefore, we think MTA is suitable for endodontic use in clinical practice.

1 Torabinejad M, Watson T, Ford T. Sealing ability of a mineral trioxide aggregate when used as a root end filling material. J Endod 1993; 19(13): 591-595.

2 Hachmeister DR, Schindler WG, Walker WA et al. The sealing ability and retention characteristics of mineral trioxide aggregate in a model of apexification. J Endod 2002; 28(5): 386-390.

3 Huang TH, Shie MY, Kao CT et al. The effect of setting accelerator on properties of mineral trioxide aggregate. J Endod 2008; 34(5): 590-593.

4 Lee E. A new mineral trioxide aggregate root-end filling technique. J Endod 2000; 26(12): 764-765.

5 Chang SW, Oh TS, Lee W et al. Long-term observation of the mineral trioxide aggregate extrusion into the periapical lesion: a case series. Int J Oral Sci 2013; 5(1): 54-57. 
6 Torabinejad M, Parirokh M. Mineral trioxide aggregate: a comprehensive literature review -Part II: leakage and biocompatibility investigations. J Endod 2010; 36(2): 190-202.

7 Liu W, Peng W, Zhu Y et al. Physicochemical properties and in vitro biocompatibility of a hydraulic calcium silicate/tricalcium aluminate cement for endodontic use. J Biomed Mater Res Part B Appl Biomater 2012; 100(5): 1257-1263.

8 Kao CT, Shie MY, Huang TH et al. Properties of an accelerated mineral trioxide aggregate-like root-end filling material. J Endod 2009; 35(2): 239-242.

9 Chen CL, Huang TH, Ding SJ et al. Comparison of calcium and silicate cement and mineral trioxide aggregate biologic effects and bone markers expression in MG63 cells. J Endod 2009; 35(5): 682-685.

10 Shie MY, Ding SJ. Integrin binding and MAPK signal pathways in primary cell responses to surface chemistry of calcium silicate cements. Biomatereials 2013; 34(28): 6589-6606.

11 Chen CL, Kao CT, Ding SJ et al. Expression of the inflammatory marker cyclooxygenase-2 in dental pulp cells cultured with mineral trioxide aggregate or calcium silicate cements. J Endod 2010; 36(3): 465-468.

12 Gomes AC, Gomes-Filho JE, de Oliveira SH. MTA-induced neutrophil recruitment: a mechanism dependent on IL-1 $\beta$, MIP-2, and LTB4. Oral Surg Oral Med Oral Pathol Oral Radiol Endod 2008; 106(3): 450-456.

13 Hung CJ, Kao CT, Shie MY et al. Comparison of host inflammatory responses between calcium-silicate base material and intermediate restorative material. J Dent Sci2013; doi:10.1016/j.jds.2013.08.002. [Epub ahead of press].

14 Yaltirik M, Ozbas H, Bilgic B et al. Reactions of connective tissue to mineral trioxide aggregate and amalgam. J Endod 2004; 30(2): 95-99.

15 Salmon M, Scheel-Toellner D, Huissoon AP et al. Inhibition of T cell apoptosis in the rheumatoid synovium. J Clin Invest 1997; 99(3): 439-446.

16 Shie MY, Huang TH, Kao CT et al. The effect of a physiologic solution $\mathrm{pH}$ on properties of white mineral trioxide aggregate. J Endod 2009; 35(1): 98-101.

17 Gough JE, Jones JR, Hench LL. Nodule formation and mineralisation of human primary osteoblasts cultured on a porous bioactive glass scaffold. Biomaterials 2004; 25(11): 2039-2046.

18 Shie MY, Ding SJ, Chang HC. The role of silicon in osteoblast-like cell proliferation and apoptosis. Acta Biomater 2011; 7(6): 2604-2614.

19 Chou MY, Kao CT, Hung CJ et al. Role of the 338 pathway in calcium silicate cementinduced cell viability and angiogenesis-related proteins of human dental pulp cell in vitro. J Endod 2013; doi:10.1016/j.joen.2013.09.041. [Epub ahead of press].

20 Huang Z, Cheng SL, Slatopolsky E. Sustained activation of the extracellular signalregulated kinase pathway is required for extracellular calcium stimulation of human osteoblast proliferation. J Biol Chem 2001; 276(24): 21351-21358.

21 Huang TH, Yang CM, Ding SJ et al. Inflammatory cytokines reaction elicited by rootend filling materials. J Biomed Mater Res Part A 2005; 73(1): 123-128.

22 Vosoughhosseini S, Lotfi M, Shahi S et al. Influence of white versus gray mineral trioxide aggregate on inflammatory cells. J Endod 2008; 34(6): 715-717.

23 Namazikhah MS, Nekoofar MH, Sheykhrezae MS et al. The effect of $\mathrm{pH}$ on surface hardness and microstructure of mineral trioxide aggregate. Int Endod J 2008; 41(2): 108-116.
24 Zhao W, Chang J, Wang J et al. In vitro bioactivity of novel tricalcium silicate ceramics. J Mater Sci Mater Med 2007; 18(5): 917-923.

25 Gandolfi M, Taddei P, Tinti A et al. Apatite-forming ability (bioactivity) of ProRoot MTA. Int Endod J 2010; 43(10): 917-929.

26 Barry MA, Eastman A. Endonuclease activation during apoptosis: the role of cytosolic $\mathrm{Ca}^{2+}$ and pH. Biochem Biophys Res Commun 1992; 186(2): 782-789.

27 Shrode LD, Tapper H, Grinstein S. Role of intracellular $\mathrm{pH}$ in proliferation, transformation, and apoptosis. J Bioenerg Biomembr 1997; 29(4): 393-399.

28 Furlong IJ, Ascaso R, Rivas AL et al. Intracellular acidification induces apoptosis by stimulating ICE-like protease activity. J Cell Sci 1997; 110(5): 653-661.

29 Hosoya S, Matsushima K. Stimulation of interleukin-1 $\beta$ production of human dental pulp cells by Porphyromonas endodontalis lipopolysaccharide. J Endod 1997; 23(1): 39-42.

30 Lee $\mathrm{NH}$, Lee $\mathrm{YH}$, Bhattari G et al. Reactive oxygen species removal activity of davallialactone reduces lipopolysaccharide-induced pulpal inflammation through inhibition of the extracellular signal-regulated kinase $1 / 2$ and nuclear factor kappa B pathway. J Endod 2011; 37(4): 491-495.

31 Coil J, Tam E, Waterfield JD. Proinflammatory cytokine profiles in pulp fibroblasts stimulated with lipopolysaccharide and methyl mercaptan. J Endod 2004; 30(2): 88-91.

32 D'Souza R, Brown LR, Newland JR et al. Detection and characterization of interleukin1 in human dental pulps. Arch Oral Biol 1989; 34(5): 307-313.

33 Xynos I, Edgar AJ, Buttery LD et al. Ionic products of bioactive glass dissolution increase proliferation of human osteoblasts and induce insulin-like growth factor I mRNA expression and protein synthesis. Biochem Biophys Res Commun 2000; 276(2): 461-465.

34 Shie MY, Chang HC, Ding SJ. Effects of altering the Si/Ca molar ratio of a calcium silicate cement on in vitro cell attachment. Int Endod J 2012; 45(4): 337-345.

35 Chen CC, Wang WC, Ding SJ. In vitro physiochemical properties of a biomimetic gelatin/chitosan oligosaccharide/calcium silicate cement. J Biomed Mater Res Part B App/ Biomater 2010; 95(2): 456-465.

36 Brigotti M, Petronini PG, Carnicelli D et al. Effects of osmolarity, ions and compatible osmolytes on cell-free protein synthesis. Biochem J 2003; 369(2): 369-374.

37 Chen M, Hu DN, Pan Z et al. Curcumin protects against hyperosmoticity-induced $\mathrm{IL}-1 \beta$ elevation in human corneal epithelial cell via MAPK pathways. Exp Eye Res 2010; 90(3): 437-443.

38 Shahi S, Rahimi S, Yavari $\mathrm{H}$ et al. Effect of mineral trioxide aggregates and portland cements on inflammatory cells. J Endod 2010; 36(5): 899-903.

39 Gomes-Filho JE, Rodrigues G, Watanabe $\mathrm{S}$ et al. Evaluation of the tissue reaction to fast endodontic cement (CER) and angelus MTA. J Endod 2009; 35(10): 1377-1380.

cc)(1) (2) This work is licensed under a Creative Commons Attribution-

cc. 1 BY NC SA NonCommercial-ShareAlike 3.0 Unported License. The images or other third party material in this article are included in the article's Creative Commons license, unless indicated otherwise in the credit line; if the material is not included under the Creative Commons license, users will need to obtain permission from the license holder to reproduce the material. To view a copy of this license, visit http://creativecommons.org/licenses/by-nc-sa/3.0/ 